Poznańskie Studia Teologiczne 30(2016), s. 463-475.

doi: $10.14746 /$ pst.2016.30.23

Jerzy Adamczyk ${ }^{1}$

Wyższe Seminarium Duchowne w Radomiu

\title{
Źródła i przedmiot nauczania katechetycznego w ujęciu prawa kanonicznego
}

\section{Wstęp}

Słowo Boże jest pojęciem bogatym znaczeniowo, mocno zakorzenionym w żydowskich i chrześcijańskich pismach świętych oraz w późniejszych tradycjach teologicznych. Słowo to środek samoobjawienia się Boga ludzkości niezależnie od formy, jaką przybiera. Bóg objawia się przez nie swojemu ludowi. Dla chrześcijan definitywną ekspresją tego słowa jest wcielenie, Logos przyjął ciało w Osobie Jezusa Chrystusa. Jednak objawienie Boga nie ustało wraz z apostolskim doświadczeniem śmierci i zmartwychwstania Chrystusa. Bóg obecnie nadal mówi w świecie na rozmaite sposoby².

Dla chrześcijan podstawowym, normatywnym sposobem, poprzez który Bóg nadal komunikuje swój zamiar i wolę, jest Biblia. Pismo Święte to zapis słowa Bożego, poprzez które Bóg przemawia w historii zbawienia (słowa i wydarzenia). Jednak nie jest to zwyczajna historia minionych zdarzeń; dla ludzi wierzących jest to niepowtarzalny sposób, przez który Bóg objawia się dzisiaj; jest to prawdziwie słowo Boże w przeciwieństwie do jakiejkolwiek innej formy objawienia. Bóg także nadal przekazuje swoje słowo poprzez tradycję Kościoła. Tradycja to proces przekazywania i ponownego asymilowania wiary apostolskiej przez kolejne pokolenia wyznawców religii chrześcijańskiej. W katolickiej teologii Pismu Świętemu i Tradycji przyznaje się jednakowo ważne miejsce, ponieważ tworzą one razem jeden święty depozyt słowa Bożego powierzony Kościołowi ${ }^{3}$.

Posługa słowa w najszerszym sensie to komunikacja słowa Bożego przez Kościół; to proklamacja Ewangelii wszystkim narodom we wszystkich pokole-

\footnotetext{
${ }^{1}$ Jerzy Adamczyk ks. dr hab. Prezbiter diecezji radomskiej. Wykładowca prawa kanonicznego w WSD w Radomiu.

2 Por. J. Huels, The Ministry of the Divine Word (Canons 756-761), „Studia canonica” 23(1989), z. 2, s. 343.

${ }^{3}$ Por. tamże.
} 
niach, przez wierne i integralne przedstawianie tajemnicy Chrystusa. Według Ogólnej instrukcji katechetycznej ,posługa słowa jest przekazywaniem orędzia zbawienia: niesie ludziom ewangelię"4.

Nowy Testament używa kilku wyrażeń określających przedmiot posługi słowa: Królestwo Boże, słowo Boże, tajemnica (misterium), dobra nowina. Wszystkie one oznaczają ostatecznie tę samą rzeczywistość - głosić Chrystusa - ukrzyżowanego i wywyższonego Zbawiciela. Chrystus to treść i przedmiot posługi słowa. Celem posługi słowa Bożego jest komunikowanie orędzia zbawienia: by nieść Ewangelię ludzkości, by uczynić Chrystusa obecnym w świecie przez słowo i sakrament, by kształtować i wychować wspólnoty wiary ${ }^{5}$.

Podstawową cechą słowa Bożego z punktu widzenia prawnego jest to, że słowo, które jest z Boga, „ofiaruje się”, aby być przekazywane. Słowo, objawienie, jest darem Boga dla wszystkich ludzi. Właśnie przez to bycie darem istnieje prawo do otrzymania słowa, prawo, które nie do Boga się odnosi (słowo Boże jest ze strony Boga zawsze darem), lecz do ludzi, do konkretnych osób, które są zobowiązane przekazywać wiernie wszystkim to, co zostało im podarowane ${ }^{6}$.

Posługa słowa, ukierunkowana na Chrystusa, winna opierać się na określonych źródłach: Piśmie Świętym, Tradycji, liturgii, Magisterium i życiu Kościo$\mathfrak{1 a}^{7}$. To taksatywne wyliczenie źródeł posługi słowa pochodzi z nauki Soboru Watykańskiego II, gdzie wzywa się biskupów do czuwania nad tym, aby nauczanie katechetyczne było oparte na wymienionych źródłach. Kanon 760 przyjmuje soborową naukę o podstawach katechizacji, rozciagając ją na całą posługę słowa, w tym oczywiście na nauczanie katechetyczne ${ }^{8}$. Osoby przekazujące słowo

${ }^{4}$ Directorium Catechisticum Generale (11 aprilis 1971), nr 16, Libreria Editrice Vaticana 1971, tekst polski: Ogólna instrukcja katechetyczna, „Wiadomości Archidiecezjalne Warszawskie” 63(1973), nr 2, s. 37-112, (odtąd: DCG).

${ }^{5}$ Por. J. Huels, The Ministry of the Divine Word, dz. cyt., s. 333.

${ }^{6}$ Por. J. Fuentes, Comentario al can. 760, w: Comentario exegético al Código de Derecho Canónico, red. A. Marzoa, J. Miras, R. Rodríguez-Ocaña, t. 3, cz. I, Pamplona 2002³ , s. 93-94. „Każdy z uczniów Jezusa ma prawo otrzymać «słowo wiary», pełne i całkowite w swej ostrości i sile”. Joannes Paulus P.P. II, Adhortatio Apostolica, Catechesi tradendae (16 octobris 1979), nr 30, „Acta Apostolicae Sedis” 71(1979), 1277-1340, tekst polski: Katecheza po Soborze Watykańskim II w świetle dokumentów Kościoła, red. W. Kubik cz. II, Warszawa 1985, s. 146-217, (odtąd: CT). Warto dodać, że pewne części adhortacji Catechesi tradendae są jednym ze źródeł aktualnego kan. 760. Pontificia Commissio Codici Iuris Canonici Authentice Interpretando, Codex Iuris Canonici Auctoritate Ioannis Pauli PP. II promulgatus. Fontium annotatione et indice analiticoalphabetico auctus, Libreria Editrice Vaticana 1989, przypis do kan. 760.

${ }^{7}$ Por. kan. 760. Trzeba zauważyć, że w schemacie Kodeksu z 1977 r. norma kanoniczna o źródłach posługi słowa Bożego nie występuje. Zob. Pontificia Commissio Codici Iuris Canonici Recognoscendo, Schema canonum libri III De ecclesiae munere docendi, can. 7-10, Città del Vaticano 1977, tekst polski: Posoborowe prawodawstwo kościelne, t. 11 z. 1, nr 21077-21259, s. 286-328.

${ }^{8}$ Concilium Oecumenicum Vaticanum II, Decretum de pastorali Episcoporum munere in Ecclesia Christus Dominus, nr 14, „Acta Apostolicae Sedis” 58(1966), s. 673-701, tekst polski: Sobór Watykański II, Dekret o pasterskich zadaniach biskupów w Kościele Christus Dominus, w: So- 
Boże posługują się różnymi środkami, przede wszystkim przepowiadaniem słowa i nauczaniem katechetycznym?.

Przedmiotem niniejszego opracowania będzie przedstawienie zagadnienia źródeł i przedmiotu nauczania katechetycznego na podstawie prawa kanonicznego. Najpierw sukcesywnie omówi się źródła katechezy: Pismo Święte, Tradycję, liturgię oraz Magisterium i życie Kościoła. Z kolei uwaga zostanie zwrócona na sprawę przedmiotu nauczania katechetycznego.

\section{Pismo Święte}

Prawodawca kodeksowy w kan. 760 jako pierwsze, podstawowe źródło katechezy, wymienia Pismo Święte ${ }^{10}$, gdyż „Pismo Święte jest mową Bożą, utrwaloną pod natchnieniem Ducha Świętego na piśmie"11.

W językach semickich wypowiedziane słowo jest utożsamiane $\mathrm{z}$ wypowiadającym je, choć słowo i mówca nie są tożsame. Mówiący istnieje wcześniej od wypowiadanego słowa; Bóg jest przed historią ludzką. Słowo jest sposobem, poprzez który Bóg przemawia w historii ludzkości, jest środkiem samoobjawienia się Boga, odwołuje się do wszelkich ludzkich sposobów, aby zakomunikować wolę Boga i Jego zamiary wobec ludzi. Jednak słowo Boże nie powinno być utożsamiane wyłącznie z jakimkolwiek środkiem, łącznie z hebrajskim i chrześcijańskim Pismem Świętym. Objawienie Boga dokonuje się w ciągu całej historii, nie tylko dla jednej grupy ludzi w jednym czasie ${ }^{12}$.

Jednak dla żydów i chrześcijan Biblia ma wyjątkowe znaczenie i jest podstawowym źródłem norm, odmiennym w stosunku do innych sposobów objawiania się Boga. Jest zapisem przymierza Boga z Jego ludem, Izraelem; opowiada, w jaki sposób Bóg „objawił się słowami i czynami [...] jako jedyny, prawdziwy i żywy Bóg”"13.

Pismo Święte, natchnione przez Boga i spisane raz na zawsze, niezmiennie przekazuje słowo Boże i sprawia, że w wypowiedziach apostołów i proroków

bór Watykański II, Konstytucje, dekrety, deklaracje. Tekst polski. Nowe tlumaczenie, Poznań 2002, s. 236-258, (odtąd: CD); por. J. Fuentes, Comentario al can. 760, s. 95; por. P. Urso, Il ministero della parola divina: predicazione e catechesi (cann. 756-780), w: La funzione di insegnare della Chiesa, a cura del Gruppo Italiano Docenti di Diritto Canonico, Milano 1994, s. 29.

${ }^{9}$ Por. J. Huels, The Ministry of the Divine Word, dz. cyt., s. 343.

${ }^{10} \mathrm{Na}$ Pismo Święte jako źródło posługi słowa Bożego wskazuje kan. 715 schematu KPK z 1980 r. (Schema Codicis Iuris Canonici, Libreria Editrice Vaticana 1980), jak również kan. 760 schematu KPK z 1982 r. (Codex Iuris Canonici, Schema novissimum iuxta placita Patrum Commissionis emendatum atque Summo Pontifici praesentatum, Typis Polyglottis Vaticanis 1982).

${ }^{11}$ Dyrektorium ogólne o katechizacji (15 sierpnia 1997), nr 96, Poznań 1998 (odtąd: DOK).

${ }^{12}$ Por. J. Huels, The Ministry of the Divine Word, s. 328-329.

${ }^{13}$ Concilium Oecumenicum Vaticanum II, Constitutio dogmatica de Divina Revelatione Dei Verbum, nr 14, „Acta Apostolicae Sedis” 58(1966), s. 817-835, tekst polski: Sobór Watykański II, Konstytucja dogmatyczna o objawieniu Bożym Dei Verbum, w: Sobór Watykański II, Konstytucje, dekrety, deklaracje. Tekst polski. Nowe thumaczenie, Poznań 2002, s. 350-361, (odtąd: DV). 
rozbrzmiewa głos Ducha Świętego ${ }^{14}$. Biblijne słowo jest wewnętrznie związane ze słowami i czynami, przez które Bóg mówi w historii. Pismo Święte jest podstawą życia Kościoła i w konsekwencji Kościół musi zawsze być w dialogu z biblijnym słowem Bożym, by zagwarantować autentyczność swojej tradycji ${ }^{15}$. Redaktorzy Dyrektorium ogólnego o katechizacji piszą, że

konstytucja Dei Verbum Soboru Watykańskiego II podkreśliła podstawowe znaczenie Pisma Świętego w życiu Kościoła. Jest ono przedstawiane wraz ze świętą Tradycją jako „najwyższa reguła wiary”, gdyż przekazuje „,łowo Boże” i sprawia, że „rozbrzmiewa głos Ducha Świętego". Dlatego Kościół chce, by w całej posłudze słowa Pismo Święte zajmowało najważniejsze miejsce ${ }^{16}$.

Jan Paweł II pisał w adhortacji Catechesi tradendae, że „mówić o [...] Piśmie Świętym jako o źródle katechezy, to podkreślać, że powinna ona być przepełniona i przeniknięta myślą, duchem i podstawami biblijnymi i ewangelicznymi przez stały kontakt z samymi tekstami" ${ }^{\prime 1}$.

W Piśmie Świętym bowiem zawarte jest objawienie, przez które „Bóg zechciał ukazać i ofiarować siebie samego oraz odwieczne zamiary swej woli”" ${ }^{18}$. Dlatego „katecheza będzie zawsze czerpać swoją treść z żywego źródła słowa Bożego, przekazanego przez Tradycję i Pismo Święte, gdyż Święta Tradycja i Pismo Święte stanowią jeden depozyt słowa Bożego powierzony Kościołowi”19. Pismo Święte winno być podstawowym ,punktem odniesienia inspirującymi całą działalność katechetyczną Kościoła w naszych czasach”20.

\section{Tradycja}

Prawodawca kodeksowy w kan. 760 jako kolejne, podstawowe źródło katechezy, wymienia Tradycję ${ }^{21}$, „której bogactwo przenika działanie i życie wierzącego i modlącego się Kościoła"22.

${ }^{14}$ Por. DV, nr 21; por. J. Huels, The Ministry of the Divine Word, dz. cyt., s. 329.

${ }^{15}$ Por. J. Huels, The Ministry of the Divine Word, dz. cyt., s. 330.

${ }^{16}$ DOK, nr 127; por. J. Dyduch, Misja przepowiadania w powszechnym prawodawstwie kościelnym, w: Stuga Slowa, red. W. Przyczyna, Kraków 1997, s. 33.

${ }^{17} \mathrm{CT}$, nr 27. „Sobór Watykański II, pragnął, by posługa słowa, czyli kaznodziejstwo, katecheza i wszelkie nauczanie chrześcijańskie słowem Pisma świętego żywiły się również korzystnie i święcie się przez nie rozwijały", tamże.

${ }^{18} \mathrm{DV}, \mathrm{nr}$ 6; por. A. Urru, La funzione di insegnare della Chiesa. Nella legislazione attuale, Roma 2001, s. 66.

${ }^{19}$ DOK, nr 94. „Treść katechezy zawiera się w słowie Bożym pisanym [...]”. DCG, nr 45.

${ }^{20} \mathrm{DOK}, \mathrm{nr} 128$.

${ }^{21} \mathrm{Na}$ Tradycję jako źródło posługi słowa Bożego wskazuje kan. 715 schematu KPK z 1980 r. (Schema Codicis Iuris Canonici, Libreria Editrice Vaticana 1980), jak również kan. 760 schematu KPK z 1982 r. (Codex Iuris Canonici, Schema novissimum iuxta placita Patrum Commissionis emendatum atque Summo Pontifici praesentatum, Typis Polyglottis Vaticanis 1982).

${ }^{22} \mathrm{DV}$, nr 8. 
Objawienie Boga ludzkości nie ustało po śmierci apostołów, ale Jego słowo nadal jest wypowiadane w historii.

Objawienie Boże, osiągające punkt kulminacyjny w Jezusie Chrystusie, jest przeznaczone dla całej ludzkości [...]. Aby wypełnić ten zamysł Boży, Jezus Chrystus założył Kościół na fundamencie Apostołów i - posyłając im od Ojca Ducha Świętego wysłał ich, by na całym świecie przepowiadali Ewangelię. Apostołowie słowami, czynami i pismami wiernie wypełnili ten nakaz. Ta Tradycja apostolska przedłuża się w Kościele i przez Kościół. Cały zaś Kościół, pasterze i wierni, czuwa nad jej zachowywaniem i przekazywaniem. Ewangelia jest więc w sposób integralny i żywy zachowywana w Kościele. Uczniowie Jezusa Chrystusa nieprzerwanie kontemplują ją i medytują przeżywają ją w codziennym życiu i głoszą ją w swojej misji. Duch Święty ożywia stale Kościół, gdy przeżywa on Ewangelię; sprawia, że ciagle wzrasta on w rozumieniu siebie samego, kieruje nim i podtrzymuje go w głoszeniu Ewangelii na całym świecie ${ }^{23}$.

„To zaś, co zostało przekazane przez apostołów obejmuje wszystko, co pomaga Ludowi Bożemu prowadzić święte życie oraz przyczynia się do wzrostu jego wiary. W ten sposób Kościół w swojej doktrynie, w życiu i kulcie przedłuża i przekazuje wszystkim pokoleniom wszystko, czym jest i w co wierzy"24.

Jan Paweł II pisał w adhortacji Catechesi tradendae, że „mówić o [...] Tradycji jako o źródle katechezy, to podkreślać, że powinna ona być przepełniona i przeniknięta myślą, duchem i podstawami biblijnymi i ewangelicznymi przez stały kontakt z samymi tekstami”25, jak również

katecheza będzie zawsze czerpać swoją treść z żywego źródła Słowa Bożego, przekazanego przez Tradycję i Pismo święte, gdyż „Święta Tradycja i Pismo święte stanowią jeden święty depozyt Słowa Bożego powierzony Kościołowi” - jak to przypomniał Sobór Watykański II, pragnąc, by ,posługa słowa, czyli kaznodziejstwo, katecheza i wszelkie nauczanie chrześcijańskie... słowem Pisma świętego żywiły się również korzystnie i święcie się przez nie rozwijały"26.

\section{Liturgia}

Następnym, podstawowym źródłem katechezy według kan. 760 jest liturgia ${ }^{27}$ „przez którą Bóg otrzymuje doskonałą chwałę a ludzie doznają uświęcenia [...]

${ }^{23} \mathrm{DOK}, \mathrm{nr} 42-43$.

${ }^{24}$ DV, nr 8; por. J. Huels, The Ministry of the Divine Word, dz. cyt., s. 331.

${ }^{25} \mathrm{CT}$, nr 27. „Sobór Watykański II, pragnął, by posługa słowa, czyli kaznodziejstwo, katecheza i wszelkie nauczanie chrześcijańskie słowem Pisma świętego żywiły się również korzystnie i święcie się przez nie rozwijały" - tamże.

${ }^{26} \mathrm{CT}, \mathrm{nr} 27$.

${ }^{27} \mathrm{Na}$ liturgię jako źródło posługi słowa Bożego wskazuje kan. 715 schematu KPK z 1980 r. (Schema Codicis Iuris Canonici, Libreria Editrice Vaticana 1980), jak również kan. 760 schematu 
Kościół [...] wzywa swego Pana, przez Niego oddaje cześć wiecznemu Ojcu"28, w której „słowo Boże zawarte w świętej Tradycji i w Piśmie Świętym [...] [jest] celebrowane, gdzie stale jest głoszone, słuchane, przeżywane i komentowane" ${ }^{\text {"2 }}$, lex orandi lex credendi ${ }^{30}$.

Liturgia jest najważniejszym, po Piśmie Świętym i Tradycji źródłem wiary. W niej ma miejsce głoszenie i świadectwo wiary, poprzez znaki i symbole uczy ona, jakie powinno być życie chrześcijańskie. Wskazuje na ścisłe powiązanie miłości Boga i bliźniego, prowadzi do spotkania z Bogiem oraz wychowuje do coraz większej troski o człowieka i jego świat. W liturgii dokonuje się dialog między Bogiem a człowiekiem. W dialogu tym Bóg wzywa, a wspólnota odpowiada. Skoro zaś celem nauczania katechetycznego jest wychowanie do wiary, to jednocześnie to nauczanie musi wprowadzać do liturgii, do świadomego i czynnego współuczestniczenia w niej ${ }^{31}$.

Directorium Catechisticum Generale wskazuje: „treść katechezy zawiera się w słowie Bożym pisanym lub przekazywanym [...] jest przedmiotem czci w liturgii [...]”32, stanowiąc dla katechezy źródło. Tak więc „katecheza z natury swej jest związana z całym sprawowaniem liturgii i sakramentów, gdyż właśnie w sakramentach, a zwłaszcza w Eucharystii, Jezus Chrystus działa najpełniej w celu przemiany człowieka" 33 .

Na konieczność liturgicznego wymiaru katechezy zwracają uwage autorzy Direttorio Generale per la Catechesi w następujących słowach:

„katecheza z natury swej jest związana z całym sprawowaniem liturgii i sakramentów”. Praktyka katechetyczna często jednak poświadcza słaby i fragmentaryczny związek z liturgią. Wyraża się to w przywiązywaniu małej wagi do znaków i obrzędów liturgicznych, niewielkim dowartościowaniu źródeł liturgicznych, działaniach

KPK z 1982 r. (Codex Iuris Canonici, Schema novissimum iuxta placita Patrum Commissionis emendatum atque Summo Pontifici praesentatum, Typis Polyglottis Vaticanis 1982).

${ }^{28}$ Concilium Oecumenicum Vaticanum II, Constitutio de sacra Liturgia Sacrosanctum Concilium, nr 7, „Acta Apostolicae Sedis” 56(1964), s. 97-138, tekst polski: Sobór Watykański II, Konstytucja o liturgii świętej Sacrosanctum Concilium, w: Sobór Watykański II, Konstytucje, dekrety, deklaracje. Tekst polski. Nowe tlumaczenie, Poznań 2002, s. 48-78.

${ }^{29}$ DOK, nr 95.

${ }^{30}$ Por. A. Urru, La funzione di insegnare, dz. cyt., s. 66. „Sama liturgia jest modlitwą; wyznanie wiary znajduje właściwy kontekst w sprawowaniu kultu. Łaska, owoc sakramentów, jest niezbędnym warunkiem chrześcijańskiego postępowania, podobnie jak udział w liturgii Kościoła wymaga wiary" - DOK, nr 122.

${ }^{31}$ Por. J. Szpet, Dydaktyka katechezy, Poznań 1999, s. 75-76.

${ }^{32}$ DCG, nr 45; zob. J. Huels, The Ministry of the Divine Word, dz. cyt., s. 343.

${ }^{33} \mathrm{CT}$, nr 23; por. nr 27. „Ci, którzy poruszeni przez łaskę postanawiają iść za Chrystusem, są wtajemniczani «w życie wiary, liturgii i miłości ludu Bożego». Kościół realizuje tę funkcję przede wszystkim za pośrednictwem katechezy, w ścisłym związku z sakramentami, tak w przypadku, gdy mają być przyjęte, jak i w przypadku, gdy już zostały przyjęte”. DOK, nr 51; por. J. Dyduch, Misja przepowiadania, dz. cyt., s. 33-34. 
katechetycznych mało związanych lub wcale nie związanych z rokiem liturgicznym, marginesowej obecności celebracji w ramach procesów katechetycznych ${ }^{34}$.

Racją katechezy jest to, że przygotowuje do sakramentów, bowiem ,życie sakramentalne ubożeje i bardzo szybko zostaje sprowadzone do zewnętrznego rytualizmu, jeśli nie jest oparte na pogłębionej znajomości znaczenia sakramentów, a sama katecheza, jeśli nie jest ożywiana życiem sakramentalnym, przybiera formę czystego intelektualizowania" 35 .

Wobec tego trzeba stwierdzić, że katecheza powinna prowadzić do liturgii, a ta ostatnia wymaga katechezy. Nauczanie katechetyczne winno być przeniknięte liturgią: znakami, czynnościami, cyklem roku liturgicznego, musi w tę rzeczywistość wprowadzać i włączać ${ }^{36}$.

\section{Magisterium i życie Kościoła}

Do źródeł posługi słowa Bożego, a więc i katechezy kan. 760 zalicza także Magisterium i życie Kościoła. Magisterium Kościoła jest gwarancją bezbłędności i nieomylności posługi słowa Bożego, stąd jest ważnym źródłem katechezy. „Urząd Nauczycielski ma zadanie «autentycznej interpretacji słowa Bożego»; wypełnia w ten sposób w imieniu Jezusa Chrystusa podstawową służbę eklezjalną. Tradycja, Pismo Święte i Urząd Nauczycielski Kościoła, wewnętrznie połączone i powiązane, «każde na swój sposób» są głównymi źródłami katechezy"37. Stąd „wykład katechetyczny ma za konieczną i wyjątkową przewodniczkę «regułę wiary», wyjaśnianą przez Urząd Nauczycielski Kościoła i pogłębianą przez teologię $e^{38}$.

Zadanie [...] autentycznego wyjaśniania słowa Bożego, spisanego bądź przekazanego w Tradycji, zostało powierzone samemu tylko żywemu Urzędowi Nauczycielskiemu Kościoła, który autorytatywnie działa w imieniu Jezusa Chrystusa. Ten Urząd Nauczycielski nie jest ponad słowem Bożym, lecz jemu służy, nauczając jedynie tego, co zostało przekazane. Z nakazu Bożego i przy pomocy Ducha Świętego pobożnie słucha on słowa Bożego, święcie strzeże i wiernie wykłada. I wszystko, co z tego jednego depozytu wiary czerpie, podaje do wierzenia jako objawione przez Boga.

Jest więc oczywiste, że święta Tradycja, Pismo Święte i Urząd Nauczycielski Kościoła, według mądrego Bożego postanowienia, tak ściśle łączą się ze sobą i zespalają że jedno bez pozostałych nie może istnieć, a wszystkie razem, każde na swój spo-

${ }^{34}$ DOK, nr 30; por. nr 71.

${ }^{35}$ CT, nr 23; por. J. Szpet, Dydaktyka katechezy, dz. cyt., s. 76.

${ }^{36}$ Por. J. Szpet, Dydaktyka katechezy, dz. cyt., s. 76; por. DOK, nr 84-85; por. J. Dyduch, Misja przepowiadania, dz. cyt., s. 33-34.

${ }^{37}$ DOK, nr 95.

${ }^{38}$ Tamże, nr 202. 
sób, pod wpływem jednego Ducha Świętego skutecznie przyczyniają się do zbawienia dusz ${ }^{39}$.

Dla nauczania katechetycznego jednym ze źródeł, które wymienia kan. 760, jest oprócz Magisterium, także życie Kościoła. Redaktorzy Directorium Catechisticum Generale piszą, że „treść katechezy zawiera się w słowie Bożym [...], jaśnieje w życiu Kościoła, zwłaszcza w sprawiedliwych i świętych. Wreszcie w jakiś sposób może być rozpoznana w nieskażonych wartościach moralnych, które z Bożej Opatrzności istnieją w społeczności ludzkiej" "40, a Direttorio Generale per la Catechesi wyraża tę prawdę w następujący sposób: „Słowo Boże [...] jaśnieje w życiu Kościoła, w jego dwutysiącletniej historii, przede wszystkim w świadectwie chrześcijan, a szczególnie świętych; ukazuje się w autentycznych wartościach religijnych i moralnych, które jako ziarna słowa są rozsiane w społeczności ludzkiej i w różnych kulturach"41.

Angelo Urru zauważa, że źródłem katechezy jest samo życie Kościoła, który podąża drogą wyznaczoną przez Chrystusa, aby przekazywać ludziom owoce zbawienia. To życie Kościoła stanowi autentyczne kryterium interpretacji Pisma Świętego ${ }^{42}$.

Człowiek i jego problemy zawsze były obecne w katechezie. Katecheza, w kontekście zachodzących przemian, jako warunek skutecznego oddziaływania musi dostrzec konkretnego człowieka żyjącego i działającego w określonym środowisku i kulturze oraz starać się wyjść naprzeciw jego oczekiwaniom i pragnieniom. Przed katechezą stoi zadanie ukazywania możliwości realizowania tych ludzkich wartości oraz udzielanie odpowiedzi na pytania i problemy przychodzącego człowieka. Niepodjęcie ich w ramach katechezy sprawiałoby wrażenie, że zwiastowane orędzie jest mało przydatne dzisiejszemu człowiekowi i mało wartościowe. Przyczyniałoby się do pogłębienia istniejącego rozdźwięku między wiarą i życiem, braku skuteczności oddziaływań. Kościół jest świadomy, że poprzez katechezę, tak jak przez całą działalność ewangelizacyjną odpowiada na najistotniejsze pytania, które wcześniej czy później stają przed każdym człowiekiem w ciągu jego życia. Skąd wywodzi się człowiek? Dlaczego istnieje? Jaka jest jego relacja do Boga i świata niewidzialnego? Jak ma postępować, aby osiag-

${ }^{39} \mathrm{DV}, \mathrm{nr} 10$; por. A. Urru, La funzione di insegnare della Chiesa. Nella legislazione attuale, dz. cyt., s. 66.

${ }^{40}$ DCG, $\mathrm{nr} 45$; por. P. Urso, Il ministero della parola divina: predicazione e catechesi, dz. cyt., s. 45 .

${ }^{41}$ DOK, nr 95.

${ }^{42}$ La funzione di insegnare della Chiesa. Nella legislazione attuale, dz. cyt., s. 67; por. Concilium Oecumenicum Vaticanum II, Constitutio dogmatica de Ecclesia Lumen gentium (21 Novembris 1964), nr 8, „Acta Apostolicae Sedis” 57(1965), s. 5-71, tekst polski: Sobór Watykański II, Konstytucja dogmatyczna o Kościele Lumen gentium, w: Sobór Watykański II, Konstytucje, dekrety, deklaracje. Tekst polski. Nowe tłumaczenie, Poznań 2002, s. 104-166. 
nąć cel swojego życia? Dlaczego poddany jest cierpieniu i śmierci i co jest jego nadzieją? ${ }^{43}$

Wyeksplikowanie przez kan. 760 życia Kościoła i doświadczenia ludzkiego jako jednego ze źródeł katechezy wynika z przykładu samego Jezusa Chrystusa, który przedmiotem swojej troski i głoszonych przypowieści uczynił doświadczenia życiowe ludzi, oraz z natury objawienia skierowanego do człowieka i mającego być przez niego przyjęte ${ }^{44}$. Ogólna instrukcja katechetyczna stwierdza, że „,doświadczenie może sprzyjać zrozumieniu chrześcijańskiego orędzia. Doświadczenie jest pomocą $[\ldots]$ w przyswajaniu prawd zawartych w depozycie objawienia, a katecheza ma pomóc [...] w nadaniu chrześcijańskiego sensu własnej egzystencji”"45.

Zadaniem katechezy jest odczytywanie sytuacji egzystencjalnej dzisiejszego człowieka - znaków czasu, podejmowanie i rozwiązywanie ich w czasie katechezy, ponieważ „chodzi o przeniknięcie Ewangelii w najbardziej ukryte tkanki osób i narodów, od wewnątrz, do centrum życiowego i korzeni życia ich kultur"46.

Osoba prowadząca katechezę powinna dokładać wszelkiej troski, by nauczyć jej adresatów doceniać własne doświadczenia tak osobiste, jak i społeczne. Jej zadaniem jest również ukazywanie w świetle Ewangelii wypływających z tych doświadczeń problemów tak, aby obudzić w ludziach słuszne pragnienie doskonalenia własnego życia ${ }^{47}$.

\section{Przedmiot nauczania katechetycznego}

Według kan. 760 przedmiotem posługi słowa (katechezy) winna być tajemnica Chrystusa przedstawiana w całości i wiernie.

Treść posługi słowa (katechizacji) jest ta sama, co przedmiot całego munus docendi. Wzmianki odnoszące się do tego przedmiotu występują nie tylko w przywołanym kan. 760, lecz także w innych dyspozycjach księgi III KPK, gdzie stosuje się różne zwroty, które w istocie oznaczają to samo. Niektóre z nich mają charakter bardziej ogólny: tak się dzieje, kiedy wskazuje się, iż przedmiotem posługi słowa jest głoszenie „,depozytu wiary” czy „Ewangelii” "48; w innych miejscach podkreśla się, że chodzi o przekazywanie „doktryny” lub „orędzia ewangelicznego"49. W kilku miejscach uwidacznia się troska prawodawcy o to, aby przekazywać doktrynę, która jest równocześnie życiem ${ }^{50}$.

\footnotetext{
${ }^{43}$ Por. J. Szpet, Dydaktyka katechezy, dz. cyt., s. 82.

${ }^{44}$ Por. tamże; zob. J. Huels, The Ministry of the Divine Word, dz. cyt., s. 343.

${ }^{45}$ DCG, nr 74; por. J. Szpet, Dydaktyka katechezy, dz. cyt., s. 82.

${ }^{46}$ DOK, nr 109; por. J. Szpet, Dydaktyka katechezy, dz. cyt., s. 82-83.

${ }^{47}$ Por. DOK, nr 117.

${ }^{48}$ Kan. $747 \S 1,781$.

${ }^{49}$ Kan. $785 \S 1,787 \S 1$.

${ }^{50}$ Kan. 759, $767 \S 1,768 \S 1$, 773, 774; por. J. Fuentes, Comentario al can. 760, dz. cyt., s. 94.
} 
Kanon 760, przypominając, że przedmiotem posługi słowa jest „tajemnica Chrystusa", wskazuje, że treści, do których nawiązują inne kanony - niektóre mówiąc bardziej bezpośrednio o doktrynie, inne o życiu i obyczajach - mają konkretne żywotne centrum, Osobę Chrystusa ${ }^{51}$. Przedmiotem posługi słowa jest zatem ,głoszenie Chrystusa i przekazywanie Jego łaski ludziom”, połączone ze staraniem o ,przepajanie i doskonalenie duchem ewangelicznym całego porządku rzeczy doczesnych" ${ }^{52}$. Nie przekazuje się zestawu abstrakcyjnych prawd, lecz Prawdę wcieloną, przekazuje się Chrystusa ${ }^{53}$.

Gdy chodzi o przekazywanie treści katechetycznej, to prawodawca wymaga, aby była ona przedstawiana $\mathrm{w}$ całości i wiernie ${ }^{54}$.

Władza kościelna wielokrotnie przypominała, że integralne i wierne przedstawianie słowa Bożego jest obowiązkiem, który koresponduje z prawem wiernych do otrzymania pełnej prawdy. W związku z tym Jan Paweł II pisał:

aby „,danina jego wiary” była doskonała, każdy z uczniów Jezusa ma prawo otrzymać „słowo wiary”, pełne i całkowite w swej ostrości i sile; nie może ono być okaleczone, zafałszowane, lub zubożone. Kto w jakimkolwiek punkcie narusza integralność orędzia, ten tym samym niebezpiecznie wyjaławia samą katechezę i zagraża jej owocom, których mają prawo po niej oczekiwać sam Chrystus i wspólnota kościelna ${ }^{55}$.

Naukę katolicką należy przekazywać zatem w sposób pełny i zrównoważony, biorąc pod uwagę hierarchię prawd, o której mówi dekret Unitatis redintegratio $^{56}$.

${ }^{51}$ Zob. W. Góralski, Nauczycielskie zadanie Kościoła, w: Komentarz do Kodeksu Prawa Kanonicznego z 1983 roku, t. 3, Lublin 1986, s. 18.

${ }^{52}$ Concilium Oecumenicum Vaticanum II, Decretum de apostolatu Laicorum Apostolicam Actuositatem, nr 5, „Acta Apostolicae Sedis” 58(1966), s. 837-864, tekst polski: Sobór Watykański II, Dekret o apostolstwie świeckich Apostolicam Actuositatem, „Acta Apostolicae Sedis” 58(1966), 837-864, w: Sobór Watykański II, Konstytucje, dekrety, deklaracje. Tekst polski. Nowe tlumaczenie, Poznań 2002, s. 377-401; por. J. Fuentes, Comentario al can. 760, dz. cyt., s. 94-95.

${ }_{53}$ Por. Ioannes Paulus PP. II, Litterae encyclicae Redemptoris Missio (7 decembris 1990), nr 44, „Acta Apostolicae Sedis” 83(1991), s. 249-340; por. J. Fuentes, Comentario al can. 760, dz. cyt., s. 95.

${ }^{54}$ Kan. 760.

${ }^{55}$ CT, nr 30; por. J. Fuentes, Comentario al can. 760, dz. cyt., s. 94.

56 „Porównując doktryny [w dialogu ekumenicznym] niech [teologowie katoliccy] pamiętają o istnieniu porządku czy «hierarchii» prawd nauki katolickiej, ponieważ różny jest ich związek z fundamentami wiary chrześcijańskiej. W ten sposób utorowana zostanie droga, która dzięki braterskiemu współzawodnictwu pobudzi wszystkich do głębszego poznania i jaśniejszego ukazania niedościgłych bogactw Chrystusowych" - Concilium Oecumenicum Vaticanum II, Decretum de Oecumenismo Unitatis Redintegratio, „Acta Apostolicae Sedis” 57(1965), s. 90-112, tekst polski: Sobór Watykański II, Dekret o ekumenizmie Unitatis Redintegratio (21 novembris 1964), nr 11, „Acta Apostolicae Sedis” 57(1965), 90-112 w: Sobór Watykański II, Konstytucje, dekrety, deklaracje. Tekst polski. Nowe thumaczenie, Poznań 2002, s. 193-208; por. A. Urru, La funzione di insegnare della Chiesa. Nella legislazione attuale, dz. cyt., s. 65-66. 
Warto dodać, że zaniedbanie obowiązku integralnego i wiernego przedstawiania słowa Bożego (także na katechezie) przez podmioty zobowiązane do nauczania podlega sankcjom karnym ze strony kompetentnej władzy kościelnej: braterskiemu upomnieniu, naganie ${ }^{57}$, a jeśli to konieczne, sankcji karnej na podstawie kan. $1389 \S 2^{58}$. W ten sposób pasterze Kościoła starają się uniknąć szkody, którą takie działania powodują w Kościele, albo przynajmniej ją złagodzić, chroniąc w ten sposób prawo wiernych do otrzymania pełnej nauki Bożej ${ }^{59}$.

\section{Wnioski}

Na podstawie analizy przepisów prawa kodeksowego i pozakodeksowego dotyczących źródeł i przedmiotu nauczania katechetycznego należy stwierdzić, że:

1. Słowo Boże jest darem Boga dla wszystkich ludzi. Wobec tego istnieje prawo do otrzymania słowa, prawo, które nie odnosi się do Boga (słowo Boże jest ze strony Boga zawsze darem), lecz do ludzi, do konkretnych osób, które są zobowiązane przekazywać wiernie wszystkim to, co im zostało podarowane.

2. Posługa słowa, ukierunkowana na Chrystusa, winna opierać się na określonych, taksatywnie wyliczonych źródłach: Piśmie Świętym, Tradycji, liturgii, Magisterium i życiu Kościoła.

3. Pierwszym, podstawowym źródłem katechezy jest Pismo Święte, gdyż jest ono „mową Bożą, utrwaloną pod natchnieniem Ducha Świętego na piśmie".

4. Kolejnym fundamentalnym źródłem katechizacji jest według kan. 760 Tradycja, „której bogactwo przenika działanie i życie wierzącego i modlącego się Kościoła".

5. Następnym źródłem nauczania katechetycznego jest liturgia, ,przez którą Bóg otrzymuje doskonałą chwałę a ludzie doznają uświęcenia [...] Kościół [...] wzywa swego Pana, przez Niego oddaje cześć wiecznemu Ojcu".

6. Do źródeł posługi słowa Bożego, a więc i katechezy, kan. 760 zalicza także Magisterium i życie Kościoła.

7. Według kan. 760 KPK przedmiotem posługi słowa (katechezy) winna być tajemnica Chrystusa przedstawiana w całości i wiernie, z uwzględnieniem hierarchii prawd.

\footnotetext{
${ }^{57}$ Kan. 1341.

${ }^{58}$ „Kto zaś wskutek zawinionego zaniedbania podejmuje lub pomija bezprawnie z czyjąś szkodą akt władzy kościelnej, posługi albo zadania, powinien być sprawiedliwie ukarany" - Kan. 1389 § 2 .

${ }^{59}$ Por. J. Fuentes, Comentario al can. 760, dz. cyt., s. 95; zob. R. Barret, The right to adequate catechesis as a fundamental right of the faithful, „Apollinaris” 70(1997), nr 1-2, s. 185-223.
} 
8. Zaniedbanie obowiązku integralnego i wiernego przedstawiania słowa Bożego (także na katechezie) przez podmioty zobowiązane do nauczania podlega sankcjom karnym ze strony kompetentnej władzy kościelnej, w celu ochrony prawa wiernych do otrzymania pełnej nauki Bożej.

\title{
The Sources and Subject of Religious Teaching in the Context of the Canon Law
}

\begin{abstract}
The following article deals with the sources and subject of religious teaching from the canon point of view. Canon Law Code 760 specifies the Holy Bible as the first and primary source of religious education. The next fundamental source of cathesis is Tradition, then, the liturgy and the Magisterium and Church life. The subject of word ministry (religious education) should be the mystery of Christ presented entirely and faithfully, taking the law hierarchy into account.
\end{abstract}

\section{Keywords}

Catechesis, sacred Scripture, Tradition, liturgy, Magisterium of the Church, life of the Church

\section{Slowa kluczowe}

katecheza, Pismo Święte, Tradycja, liturgia, Nauczycielski Urząd Kościoła, życie Kościoła

\section{Bibliografia}

\section{Źródła}

Codex Iuris Canonici, Schema novissimum iuxta placita Patrum Commissionis emendatum atque Summo Pontifici praesentatum, Typis Polyglottis Vaticanis 1982.

Concilium Oecumenicum Vaticanum II, Constitutio de sacra Liturgia Sacrosanctum Concilium, „Acta Apostolicae Sedis”, 56(1964), s. 97-138, tekst polski: Sobór Watykański II, Konstytucja o liturgii świętej Sacrosanctum Concilium, w: Sobór Watykański II, Konstytucje, dekrety, deklaracje. Tekst polski. Nowe tłumaczenie, Poznań 2002, s. 48-78.

Concilium Oecumenicum Vaticanum II, Decretum de apostolatu Laicorum: Apostolicam actuositatem, „Acta Apostolicae Sedis” 58(1966), s. 837-864, tekst polski: Sobór Watykański II, Dekret o apostolstwie świeckich Apostolicam actuositatem, w: Sobór Watykański II, Konstytucje, dekrety, deklaracje. Tekst polski. Nowe tłumaczenie, Poznań 2002, s. 377-401.

Concilium Oecumenicum Vaticanum II, Decretum de Oecumenismo Unitatis Redintegratio, „Acta Apostolicae Sedis” 57(1965), s. 90-112, tekst polski: Sobór Watykański II, Dekret o ekumenizmie Unitatis Redintegratio, w: Sobór Watykański II, Konstytucje, dekrety, deklaracje. Tekst polski. Nowe ttumaczenie, Poznań 2002, s. 193-208.

Concilium Oecumenicum Vaticanum II, Decretum de pastorali Episcoporum munere in Ecclesia Christus Dominus, „Acta Apostolicae Sedis” 58(1966), s. 673-701, tekst polski: Sobór Watykański II, Dekret o pasterskich zadaniach biskupów w Kościele Chri- 
stus Dominus, w: Sobór Watykański II, Konstytucje, dekrety, deklaracje. Tekst polski. Nowe thumaczenie, Poznań 2002, s. 236-258.

Concilium Oecumenicum Vaticanum II, Constitutio dogmatica de Ecclesia Lumen gentium (21 Novembris 1964), „Acta Apostolicae Sedis” 57(1965), s. 5-71, tekst polski: Sobór Watykański II, Konstytucja dogmatyczna o Kościele Lumen gentium, w: Sobór Watykański II, Konstytucje, dekrety, deklaracje. Tekst polski. Nowe tłumaczenie, Poznań 2002, s. 104-166.

Concilium Oecumenicum Vaticanum II, Constitutio dogmatica de Divina Revelatione Dei Verbum, „Acta Apostolicae Sedis” 58(1966), s. 817-835, tekst polski: Sobór Watykański II, Konstytucje, dekrety, deklaracje. Tekst polski. Nowe tłumaczenie, Poznań 2002, s. 350-361.

Directorium Catechisticum Generale (11 aprilis 1971), Libreria Editrice Vaticana 1971, tekst polski: Ogólna instrukcja katechetyczna, „Wiadomości Archidiecezjalne Warszawskie" 63(1973), nr 2, s. 37-112.

Ioannes Paulus P.P. II, Adhortatio apostolica, Catechesi tradendae (16 octobris 1979), „Acta Apostolicae Sedis” 71(1979), 1277-1340, tekst polski: Jan Paweł II, Adhortacja apostolska Catechesi tradendae, w: Katecheza po Soborze Watykańskim II w świetle dokumentów Kościoła, red. W. Kubik, cz. II, Warszawa 1985, s. 146-217.

Ioannes Paulus PP. II, Litterae encyclicae Redemptoris Missio (7 decembris 1990), „Acta Apostolicae Sedis" 83(1991), s. 249-340.

Pontificia Commissio Codici Iuris Canonici Authentice Interpretando, Codex Iuris Canonici Auctoritate Ioannis Pauli PP. II promulgatus. Fontium annotatione et indice analitico-alphabetico auctus, Libreria Editrice Vaticana 1989.

Pontificia Commissio Codici Iuris Canonici Recognoscendo, Schema canonum libri III De ecclesiae munere docendi, Città del Vaticano 1977, tekst polski: Posoborowe prawodawstwo kościelne, t. 11 z. 1, nr 21077-21259, s. 286-328.

Schema Codicis Iuris Canonici, Libreria Editrice Vaticana 1980.

\section{Literatura}

Barret R., The right to adequate catechesis as a fundamental right of the faithful, ,Apollinaris" 70(1997), nr 1-2, s. 185-223.

Comentario exegético al Código de Derecho Canónico, red. A. Marzoa, J. Miras, R. Rodríguez-Ocaña, t. 3, cz. I, Pamplona $2002^{3}$.

Dyduch J., Misja przepowiadania w powszechnym prawodawstwie kościelnym, w: Stuga Słowa, red. W. Przyczyna, Kraków 1997, s. 23-35.

Góralski W., Nauczycielskie zadanie Kościoła, w: Komentarz do Kodeksu Prawa Kanonicznego z 1983 roku, t. 3, Lublin 1986, s. 12-50.

Huels J., The Ministry of the Divine Word (Canons 756-761), „Studia canonica” 23(1989), z. 2, s. 325-344.

Szpet J., Dydaktyka katechezy, Poznań 1999.

Urru A., La funzione di insegnare della Chiesa. Nella legislazione attuale, Roma 2001.

Urso P., Il ministero della parola divina: predicazione e catechesi (cann. 756-780), w: La funzione di insegnare della Chiesa, red. Gruppo Italiano Docenti di Diritto Canonico, Milano 1994, s. 25-49. 